\title{
HUMAN PAPILLOMAVIRUS AND ITS VACCINE: AWARENESS AND ATTITUDES OF YOUNG FEMALE PAKISTANI STUDENTS
}

\section{Sana Ghayas ${ }^{1 \otimes}$, Fakhsheena Anjum', Tazeen Husain², Lubna Bashir', Shazia Naz ${ }^{3}$, Muhammad Ali Masood'}

\section{ABSTRACT}

OBJECTIVE: To determine awareness about human papillomavirus (HPV) among female students of medical field in Pakistan.

METHODS: A researcher administered, descriptive cross-sectional survey was conducted on a voluntary group of participants $(n=629)$ belonging to medical field from August 2017 to December 2017. After taking permission from the administration random convenient sampling method was adopted. This survey included only female students who were currently studying in departments of medical/health sciences. Students of first and second professionals were excluded because they are beginners in medical fields.

RESULTS: The main source of information regarding HPV was academic curriculum $(38.25 \%)$ of the respondents, with only $21.70 \%$ claiming that healthcare providers had educated them about the same. However, $70.11 \%$ also reported that HPV/Pap test had never been recommended by their doctors. Many participants $36.09 \%$ had no prior knowledge of HPV vaccines; while $56.28 \%$ were willing to get vaccinated, the remaining $23.21 \%$ claimed a variety of reasons for their unwillingness and rest were uncertain. The top three reasons cited for unwillingness were being sexually inactive $54.79 \%$, the reason of not knowing anything about vaccine $6.84 \%$ and cost of vaccines $6.84 \%$.

CONCLUSION: This study established that despite having knowledge about HPV, the populace required sufficient information about HPV vaccination for its acceptance and to prevent and combat the disease.

KEY WORDS: Vaccination (MeSH); Papillomavirus Infections (MeSH); Papillomavirus Vaccines (MeSH); Uterine Cervical Neoplasms (MeSH); Human Papillomavirus (Non-MeSH); Awareness (MeSH); Students, Medical (MeSH); Students, Health Occupations (MeSH).

THIS ARTICLE MAY BE CITED AS: Ghayas S, Anjum F, Husain T, Bashir L, Naz S, Masood MA. Human papillomavirus and its vaccine: awareness and attitudes of young female Pakistani students. Khyber Med Univ J 2018; 10(4):200-5.

\section{INTRODUCTION}

W uman papillomavirus (HPV) is a widespread sexually transmitted DNA virus that infects only the epithelial cells of the host.' After entering the epithelial layer, viral gene expression begins in order to assemble infectious HPV virions in final stages of the infection. ${ }^{2}$ There are over one hundred subtypes of HPV that are classified as low-risk and high-risk depending on their probability for causing oncogenesis. ${ }^{1,2}$ HPV may manifest itself as genital warts in both men and women, cervical dysplasia, cervical or oropharyngeal cancers in some cases. ${ }^{3}$ However, most men and women infected with HPV do not show clinical symptoms of the disease and are resolved by the host's immune response within 2 years. Moreover, the progression from infection to malignancy can exceed 10 years. Therefore, cervical cancer is highest in women aged over 40 years.

Many factors may cause cervical cancer, such as number of sexual partners, age at first sexual intercourse, and sexual behavior of the male partner. ${ }^{3}$ However, genital infection with specific types of HPV is the most important risk factor.
I Dow College of Pharmacy, Dow University of Health Sciences, Karachi, Pakistan.

Email冈: sanaghayas7@hotmail.com, sana.ghayas@duhs.edu.pk Contact \#: +92-3333।I44464

2 Department of Pharmaceutics, Faculty of Pharmacy, University of Karachi, Pakistan.

3 Department of Pharmaceutics, Faculty of Pharmacy, Federal Urdu University of Arts, Science and Technology, Karachi, Pakistan

Date Submitted: May 19, 2018

Date Revised: December 17, 2018

Date Accepted: December 18,2018

Of the many subtypes of HPV subtypes $16,18,31$, and 33 are confirmed to be cancerous. These 'high-risk' subtypes have been discovered in nearly all cervical cancers. ${ }^{4}$

The Age Standardized Risk (ASR) per 100,000 women in Pakistan is 7.5 , which is lower than worldwide (ASR of I5.2 per 100,000 women). ${ }^{5}$ At any given time, nearly $0.5 \%$ of Pakistani women harbor cervical HPV $16 / 18$ infection and $88.1 \%$ invasive cervical cancers are attributable to HPV 16 or 18. ${ }^{6}$ Globally, prevalence of cervical HPV is the highest in Sub-Saharan Africa (24\%), Eastern Europe (21.4\%) and in Latin America (16\%).

Pakistan has 59.04 million women of the age 15 years and above that are at risk of cervical cancer. According to latest estimates, 5,233 women are diagnosed with cervical cancer and 2,876 die from the disease annually. It is the third most frequently occurring cancer among women in Pakistan and the second most common cancer among women aged I544 years. ${ }^{6}$ The picture is just as bleak when global figures are considered. Annually, over 470,000 new cases are reported and about 230,000 deaths are caused; nearly $80 \%$ occurring in developing nations. ${ }^{4}$

Cervical cancer is most likely to affect females that are poor, have lower education, and lower income. Differences in stage when diagnosed and mortality based on ethnicity have also been reported in literature. ${ }^{8}$ This disparity may be explained by the higher screening rates and wider acceptance of Papanicolau (Pap) test in developed countries and availability of FDA approved HPV vaccines Cervarix ${ }^{\circledR}$ (a bivalent vaccine) and Gardasil $\AA$ (the quadrivalent vaccine) ${ }^{8}$ that confer protection against HPV 16 and 18. 
TABLE I: LEVEL OF KNOWLEDGE OF STUDY PARTICIPANTS ABOUT HUMAN PAPILLOMAVIRUS AND CERVICAL CANCER

\begin{tabular}{|c|c|c|c|}
\hline Question & Response & Frequency (n) & Percentage (\%) \\
\hline \multirow{2}{*}{ Are you aware of HPV? } & Yes & 455 & 72.33 \\
\hline & No & 174 & 27.67 \\
\hline \multirow{7}{*}{$\begin{array}{l}\text { What is the source of } \\
\text { your knowledge } \\
\text { regarding HPV? }\end{array}$} & Family/friend & 11 & 2.38 \\
\hline & Newspaper & 6 & 1.43 \\
\hline & TV & 12 & 2.70 \\
\hline & Healthcare provider & 99 & 21.70 \\
\hline & Internet & 61 & 13.35 \\
\hline & Academics & 174 & 38.25 \\
\hline & Don't remember & 92 & 20.19 \\
\hline \multirow{3}{*}{ Is HPV infection rare? } & Yes & 285 & 45.31 \\
\hline & No & 217 & 34.49 \\
\hline & Don't know & 127 & 20.20 \\
\hline \multirow{4}{*}{$\begin{array}{l}\text { Which gender does } \\
\text { HPV infect? }\end{array}$} & Men & 2 & 0.32 \\
\hline & Women & 150 & 23.84 \\
\hline & Both & 467 & 74.25 \\
\hline & Don't know & 10 & 1.59 \\
\hline \multirow{3}{*}{$\begin{array}{l}\text { Is HPV sexually } \\
\text { transmitted? }\end{array}$} & Yes & 150 & 23.84 \\
\hline & No & 295 & 46.90 \\
\hline & Don't know & 184 & 29.26 \\
\hline \multirow{3}{*}{$\begin{array}{l}\text { Is incidence of HPV } \\
\text { highest in women in } \\
\text { their } 20 \text { s and } 30 \text { s? }\end{array}$} & Yes & 258 & 41.01 \\
\hline & No & 39 & 6.21 \\
\hline & Don't know & 332 & 52.78 \\
\hline \multirow{3}{*}{$\begin{array}{l}\text { Can HPV cause cervical } \\
\text { cancer? }\end{array}$} & Yes & 379 & 60.26 \\
\hline & No & 61 & 9.69 \\
\hline & Don't know & 189 & 30.05 \\
\hline \multirow{3}{*}{$\begin{array}{l}\text { Can HPV cause genital } \\
\text { warts? }\end{array}$} & Yes & 333 & 52.95 \\
\hline & No & 29 & 4.61 \\
\hline & Don't know & 267 & 42.44 \\
\hline \multirow{3}{*}{$\begin{array}{l}\text { Can both men and } \\
\text { women get cervical } \\
\text { cancer? }\end{array}$} & Yes & 60 & 9.54 \\
\hline & No & 315 & 50.07 \\
\hline & Don't know & 254 & 40.39 \\
\hline \multirow{3}{*}{$\begin{array}{l}\text { Is Pap smear a } \\
\text { screening test for } \\
\text { cervical cancer? }\end{array}$} & Yes & 281 & 44.67 \\
\hline & No & 116 & 18.44 \\
\hline & Don't know & 232 & 36.89 \\
\hline \multirow{3}{*}{$\begin{array}{l}\text { Did your doctor ever } \\
\text { mention/recommend } \\
\text { HPV/Pap test? }\end{array}$} & Yes & 98 & 15.59 \\
\hline & No & 441 & 70.11 \\
\hline & Don't know & 90 & 14.3 \\
\hline \multirow{3}{*}{$\begin{array}{l}\text { Are genital warts and } \\
\text { cervical cancer caused } \\
\text { by the same subtype of } \\
\text { HPV? }\end{array}$} & Yes & 333 & 52.95 \\
\hline & No & 29 & 4.61 \\
\hline & Don't know & 267 & 42.44 \\
\hline \multirow{3}{*}{$\begin{array}{l}\text { Is HPV infection } \\
\text { curable? }\end{array}$} & Yes & 344 & 54.69 \\
\hline & No & 57 & 9.07 \\
\hline & Don't know & 228 & 36.24 \\
\hline \multirow{3}{*}{$\begin{array}{l}\text { Can HPV infection } \\
\text { resolve itself without } \\
\text { treatment? }\end{array}$} & Yes & 45 & 7.16 \\
\hline & No & 410 & 65.18 \\
\hline & Don't know & 174 & 27.66 \\
\hline
\end{tabular}

$\mathrm{HPV}=$ human papillomavirus

The vaccines have the potential to reach high risk groups identified by various researchers $^{9-11}$ and thus reduce future health burden. Medeiros, et al. ${ }^{12}$ reported that prophylactic administration of the vaccines can prevent HPV infection in women aged $9-26$ years, provided they had not been infected with the subtypes covered by the vaccines before. The efficacy of these vaccines in men is unproven and its use for men is currently not licensed. Three doses of the vaccines are administered at intervals of $0, I$ and 6 months for Cervarix ${ }^{\circledR}$ and 0,2 and 6 months for Gardasil ${ }^{\circledR}$ as intramuscular injections.
Despite proven usefulness of the vaccines, early reports indicate lower vaccination rates among at-risk groups. $^{13,14}$ Graham and Mishra have identified high cost of the vaccines and absence of a usual care-source, as well as lack of public awareness about cervical cancer and available screening methods as hindrances to the use of these vaccines." The highest vaccine coverage in countries like Scotland and Spain etc. was achieved through schoolbased vaccination programs $s^{15,16}$ and the most prominent finding was in Uganda, attaining almost $95 \%$ coverage. ${ }^{17}$

Average monthly income in Pakistan ranged from PKR 2I ,785-37,727 in 20 I0$20 \mathrm{II}$ according to a report by the Pakistan Bureau of Statistics. ${ }^{18}$ Consequently, the high retail prices of the vaccines (Cervarix ${ }^{\circledR}$ : Rs. 4700, Gardasil ${ }^{\circledR}$ : Rs. 9000) ${ }^{19}$ render them out of the financial reach of most people. Khan S, et al ${ }^{2}$ claim that the epidemiology of HPV in Pakistan is still unclear due to social and cultural taboos on matters related to sex. Thus, there is a dearth of quantifiable data regarding HPV burden and HPV-related cervical cancer cases is the country. Nonetheless, HPV- 16 has been found in nearly every case of cervical cancer in Pakistan'. It is thus imperative that immunization of the at-risk group be carried out. However, a significant barrier to acceptability of the vaccines, apart from the factors mentioned earlier is the lack of awareness of the general population $^{8}$.

The present study aims to of awareness about human papillomavirus (HPV) among female students enrolled in different medical-related fields of study in Karachi, Pakistan. Moreover; the designed questionnaire was also utilized to explore their perceptions and the necessity/usefulness of the HPV vaccination as well. This would help to organize ways for promotion of knowledge about HPV vaccination and its acceptance for prevention and eradication of the disease associated to the virus.

\section{METHODS}

A descriptive cross sectional study was conducted using random, convenience sampling method among female medical 
TABLE II: KNOWLEDGE OF STUDY PARTICIPANTS ABOUT HUMAN PAPILLOMAVIRUS VACCINES

\begin{tabular}{|l|l|c|c|}
\hline \multicolumn{1}{|c|}{ Question } & Response & Frequency (n) & Percentage (\%) \\
\hline \multirow{3}{*}{$\begin{array}{l}\text { Have you any prior awareness } \\
\text { of HPV vaccines? }\end{array}$} & Yes & 222 & 35.30 \\
\cline { 2 - 4 } & No & 227 & 36.09 \\
\cline { 2 - 4 } & Don't know & 180 & $28.6 \mathrm{I}$ \\
\hline \multirow{3}{*}{$\begin{array}{l}\text { To whom can vaccine be } \\
\text { administered? }\end{array}$} & Men & 5 & 0.79 \\
\cline { 2 - 4 } & Women & $31 \mathrm{I}$ & 49.45 \\
\cline { 2 - 4 } & Both & 313 & 49.76 \\
\hline \multirow{3}{*}{$\begin{array}{l}\text { Age group for whom } \\
\text { vaccination be recommended? }\end{array}$} & $9-26$ years & 493 & 78.38 \\
\cline { 2 - 4 } & $27-30$ years & 103 & 16.38 \\
\cline { 2 - 4 } & $31-40$ years & 33 & 5.24 \\
\hline \multirow{2}{*}{$\begin{array}{l}\text { Do the current HPV vaccines } \\
\text { protect against genital warts } \\
\text { and cervical cancer? }\end{array}$} & Yes & 315 & 50.08 \\
\cline { 2 - 4 } & No & 30 & 4.77 \\
\cline { 2 - 4 } $\begin{array}{l}\text { Is HPV vaccine approved for } \\
\text { individuals who have never } \\
\text { been infected with HPV? }\end{array}$ & Don't know & 284 & 45.15 \\
\cline { 2 - 4 } & Yes & 286 & 45.47 \\
\cline { 2 - 4 } & No & 86 & 13.68 \\
\cline { 2 - 4 } & Don't know & 257 & 40.85 \\
\hline HPV=human paillomavirus & & \\
\hline
\end{tabular}

students of various universities. A self administered proforma was used designed from various sources and was used after taking consent from respondents. Anonymity and confidentiality of the participants were maintained. The research was conducted from Aug. 2017 to Dec. 2017. Permission to conduct survey based study was taken from the administration of the institutes. This survey included only female students who were currently studying in departments of medical/health sciences. Students of first and second professionals were excluded as they were supposed to be beginners in medical fields.

A self-administered questionnaire was prepared to check the awareness regarding cervical cancer and HPV vaccination related issues among the future healthcare providers. The questionnaire was primarily closed ended while a few open-ended questions which were divided into three sections. The first part consisted of basic information of participants and their awareness regarding cervical cancer and HPV. The second section provided knowledge based questions on cervical cancer, efficacy and safety of the HPV vaccine. The third section had questions regarding acceptance and perception of HPV vaccination, to gauge the baseline understanding of the disease and concept of vaccination. It took about 30 minutes to complete the questionnaire.

Data were checked for completeness and then entered into SPSS 21.0 for analysis. The results were summarized using descriptive statistics, expressed as mean and percentages.

\section{RESULTS}

A total of 629 female students related to medical fields participated in the study. The demographic information about the respondents is represented in Figurel.

Level of knowledge about HPV and cervical cancer among the participants is displayed in Table I. It was seen that $72.33 \%$ (455) respondents knew about HPV in which $38.25 \%$ (174) knew through their study curriculum and $21.70 \%$ (99) because of other healthcare providers. Most participants possessed basic knowledge of the virus and cervical cancer, as the students had a medical background. Majority $70.11 \%$ (44I) responded that their doctors never mentioned or recommended screening Pap test for them.

The knowledge about HPV vaccines among respondents is shown in Table ll. It was observed that overall approximately less than $50 \%$ participants were not sure of the correct answers, reflecting the need for widely disseminating information regarding the vaccine to ease cervical cancer burden.

Health status and attitude of the participants about HPV vaccination is exhibited in Table III. About 36.54\% (230) of the participants believed their health status was average and only $27.82 \%$
(175) visited a doctor regularly; just a very few $0.48 \%$ (3) had a history of tumor/cancer. It was also seen that $56.28 \%$ (354) were willing to get vaccinated and $67.89 \%$ (427) were also willing to recommend the vaccine to others.

The vaccination history of the participants is shown in Figure II, which shows that majority $73 \%$ (459) never received HPV vaccination and among those who had $5 \%$ (3I) did not get all three doses of the vaccine.

\section{DISCUSSION}

The study established that the students $72.33 \%$ were aware of HPV and cervical cancer (Table I) and the main source of information was their academic curriculum. However, the participants (approximately less than 50 $\%)$ did not have sufficient basic knowledge about the vaccines (Table II). Sufficient knowledge about HPV was also reported by an Indian study, where academics was cited as major source of information. ${ }^{20}$ Similar studies conducted in South Africa and Botswana showed HPV awareness as $26.2 \%$ and $35 \%$ respectively. ${ }^{21,22}$ A research in India, Nepal and Sri Lanka found that on average $66 \%$ Indians, $58.8 \%$ Nepalis and $57.7 \%$ Sri Lankans were aware of cervical cancer and its etiology. ${ }^{23}$

Regarding HPV vaccination, 56.28\% respondents were willing to be vaccinated (Table III). Numerous researchers have also documented the link between awareness of HPV and cervical cancer and the acceptability of HPV vaccines. ${ }^{8,24}$ From our study it was observed that $67.89 \%$ of participants were willing to recommend HPV vaccine to others. There were some countries, notably Malaysia, Kenya and Tanzania, where despite of lower level of education about HPV and cervical cancer, high levels of acceptance of the vaccines were demonstrated. The study also found that healthcare provider or clinician recommendation is also important in increasing vaccine acceptability. ${ }^{24}$

In our study, $54.79 \%$ of the participants being sexually inactive were unwilling to get vaccinated and almost the same finding is established in another research as well that the vaccines are 
TABLE III: HEALTH STATUS AND ATTITUDES REGARDING HUMAN PAPILLOMAVIRUS VACCINATION OF RESPONDENTS'

\begin{tabular}{|c|c|c|c|}
\hline Question & Response & Frequency (n) & Percentage (\%) \\
\hline \multirow{4}{*}{$\begin{array}{l}\text { Self-perception of } \\
\text { health status }\end{array}$} & Excellent & 89 & 14.14 \\
\hline & Very good & 168 & 26.75 \\
\hline & Fair & 230 & 36.54 \\
\hline & Poor & 142 & 22.57 \\
\hline \multirow{2}{*}{ Regular visit to doctor } & Yes & 175 & 27.82 \\
\hline & No & 454 & 72.18 \\
\hline \multirow{3}{*}{$\begin{array}{l}\text { History of cervical } \\
\text { tumor/cancer }\end{array}$} & Yes & 3 & 0.48 \\
\hline & No & 617 & 98.09 \\
\hline & Don't know & 9 & 1.43 \\
\hline \multirow{3}{*}{$\begin{array}{l}\text { Willing to get } \\
\text { vaccinated? }\end{array}$} & Yes & 354 & 56.28 \\
\hline & No & 146 & 23.21 \\
\hline & Undecided & 129 & 20.51 \\
\hline \multirow{11}{*}{$\begin{array}{l}\text { If not willing, then the } \\
\text { reason for } \\
\text { unwillingness? }\end{array}$} & I believe I do not need it & 10 & 6.84 \\
\hline & I am not sexually active & 80 & 54.79 \\
\hline & It is too expensive & 10 & 6.84 \\
\hline & I am too old for vaccine & 05 & 3.42 \\
\hline & $\begin{array}{l}\text { Doctor did not } \\
\text { recommend it }\end{array}$ & 06 & 4.10 \\
\hline & $\begin{array}{l}\text { Worried about safety of } \\
\text { vaccine }\end{array}$ & 06 & 4.17 \\
\hline & $\begin{array}{l}\text { Do not know where to } \\
\text { get vaccine }\end{array}$ & 04 & 2.73 \\
\hline & $\begin{array}{l}\text { My spouse/family is } \\
\text { against it }\end{array}$ & 0 & 0 \\
\hline & $\begin{array}{l}\text { I do not know enough } \\
\text { about vaccine }\end{array}$ & 10 & 6.84 \\
\hline & I already have HPV & 0 & 0 \\
\hline & Don't know & 15 & 10.27 \\
\hline \multirow{3}{*}{$\begin{array}{l}\text { Would you } \\
\text { recommend vaccine to } \\
\text { others? }\end{array}$} & Yes & 427 & 67.89 \\
\hline & No & 71 & 11.28 \\
\hline & Don't know & $|3|$ & 20.82 \\
\hline \multirow{3}{*}{$\begin{array}{l}\text { If vaccine is provided } \\
\text { free of cost, would you } \\
\text { accept it? }\end{array}$} & Yes & 379 & 60.26 \\
\hline & No & 102 & 16.22 \\
\hline & Don't know & 148 & 23.52 \\
\hline \multirow{3}{*}{$\begin{array}{l}\text { Do vaccinated women } \\
\text { no longer need annual } \\
\text { cervical cancer } \\
\text { screening test? }\end{array}$} & Yes & 98 & 15.58 \\
\hline & No & 265 & 42.14 \\
\hline & Don't know & 266 & 42.28 \\
\hline
\end{tabular}

$\mathrm{HPV}=$ human papillomavirus

intended to prevent the occurrence of a sexually transmitted virus and are administered to young girls before they make their sexual debut. ${ }^{24}$ McCafferey $\mathrm{K}$, et al. $^{25}$ in 2003 reported that among Indian, Pakistani, African-Caribbean and white British women in the UK getting tested for HPV provoked negative feelings in them, and in their point of view sent messages of promiscuity, mistrust, and unconventionality. Especially in Pakistani and Indian women where monogamy is the rule, getting vaccinated for HPV may hold significant negative social connotations. ${ }^{25}$

In our study $36.54 \%$ participants believed their health status was average; just a very few of $0.48 \%$ had a history of tumor/cancer (Table II). The vaccination history of the participants shows that majority $73 \%$ never received HPV vaccination and among those who had $5 \%$, did not get all three doses of the vaccine. Khan S, et al. ${ }^{2}$ in 2007 studied the serotype HPVI6 in 59 out of 60 cervical cancer patients at Pakistan which suggests that HPV vaccination is of particular importance in this country but social and cultural taboos regarding sex and sexual health complicate attempts to impart information about HPV, cervical cancer and the HPV vaccines. Due to strong religious and social restrictions, incidence of cervical cancer is much lower in Pakistan than elsewhere in the world. However as Jawaid A claims, norms are changing and the scenario may change drastically in a couple of decades. ${ }^{26}$

From our study (Table III) it was noted that if the vaccines were provided free of cost then their acceptance would increase from $56.28 \%$ to $60.26 \%$ among the study participants. This is corroborated by other researchers ${ }^{8,27}$ including Bhatla and Joseph (2009) who found that cost, lack of awareness, infrastructure, the side effects, social and religious concerns were some of the barriers to widespread acceptance of HPV vaccination in India. ${ }^{28}$

\section{CONCLUSION}

It was found that the participants had sufficient knowledge about HPV disease as they belonged to medical background, however the lack of information about HPV vaccination, should be addressed as the respondents are future healthcare providers and also acceptance of vaccination is necessary for prevention of this disease.

\section{LIMITATIONS AND RECOMMENDATIONS}

Present study was limited, covering only the medical students of Karachi. It was recommended that in future such investigation would be conducted on various cities of Pakistan and also compares the responses of rural and urban areas of the of Pakistan.

\section{REFERENCES}

I. Azam, F, Shams-ul-Islam M, Prevention of human papilloma virus infection with vaccines. Prevention. J Pak Med Assoc 20 I0;60(8):676-8I

2. Khan S, Jaffer NN, Khan MN, Rai MA, Shafiq M, Ali A, et al. Human papillomavirus subtype 16 is common in Pakistani women with cervical carcinoma. Int J Infect Dis 2007; I I(4):3।3-7. DOI: I0.1016/ j.ijid.2006.06.007.

3. Steben M, Duarte-Franco E. Human papillomavirus infection: epidemiology and pathophysiology. Gynecol Onco 2007;107(2 Suppl I):S2-5. DOI: 10.1016/j.ygyno.2007.07.067. 


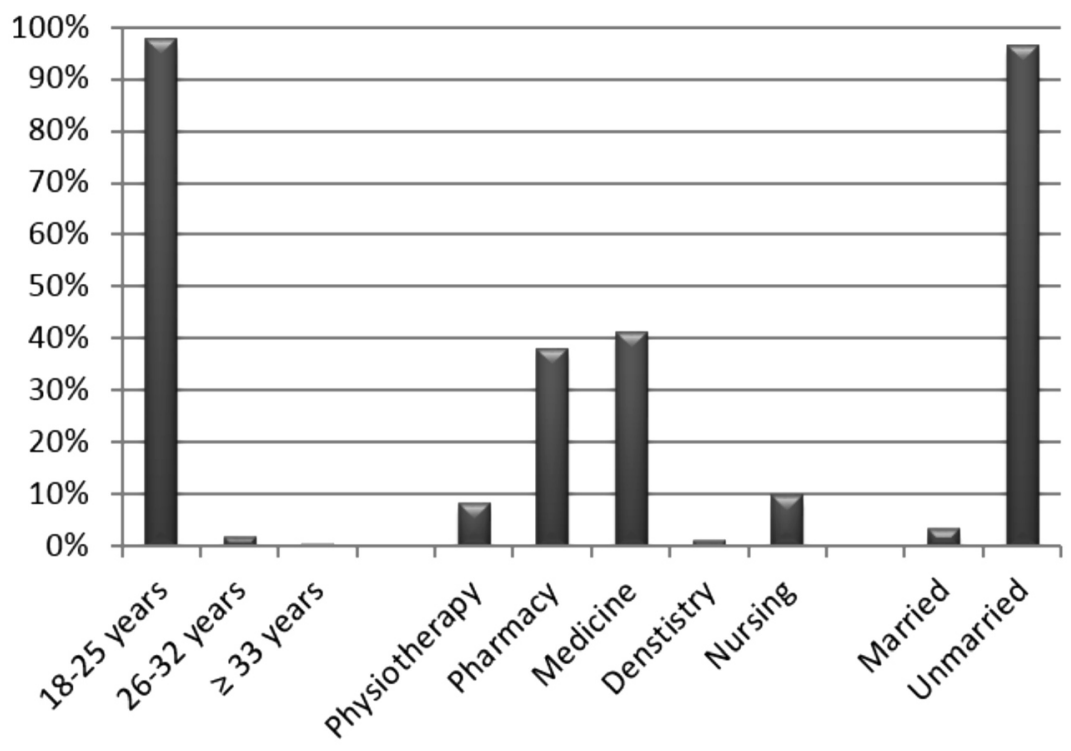

Figure I: Information about respondents

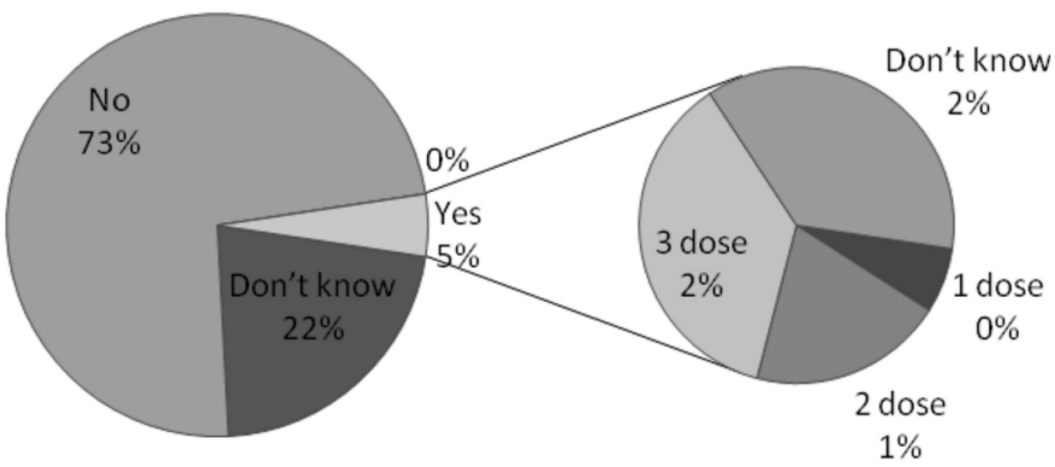

Figure 2: Vaccination history of participants

4. Badar, F, Anwar N, Meerza F, Sultan F. Cervical carcinoma in a Muslim community. Asian Pac J Cancer Prev 2007;8(I):24-6

5. Siddiqa A, Zainab M, Qadri I, Bhatti MF, Parish JL. Prevalence and genotyping of high risk human papillomavirus in cervical cancer samples from Punjab, Pakistan. Viruses 2014;6(7):2762-77. DOI: $10.3390 / v 6072762$

6. Bruni L, Barrionuevo-Rosas L, Albero G, Aldea M, Serrano B, Valencia S, et al. ICO Information Centre on HPV and Cancer (HPV Information Centre). Human Papillomavirus and Related Diseases in the World. Summary Report (Accessed on: |2-0|-20 |8).

7. Bruni L, Diaz M, Castellsagué $X$, Ferrer E, Bosch FX, de Sanjosé S. Cervical human papillomavirus prevalence in 5 continents: metaanalysis of I million women with normal cytological findings. J Infect Dis 2010;202(I2):I789-99. DOI: I0.1086/65732|

8. Do YK, Wong KY. Awareness and acceptability of human papillomavirus vaccine: an application of the instrumental variables bivariate probit model. BMC Public Health 20|2;|2:3|. DOI:|0.||86/|47| 2458-|2-3|.

9. Downs LS, Scarinci I, Einstein $M H$ Collins Y, Flowers L. Overcoming the barriers to HPV vaccination in highrisk populations in the US. Gynecol Oncol 2010;1I7(3):486-90. DOI: 10.1016/j.ygyno.2010.02.01 I

10. Singh GK, Miller BA, Hankey BF, Edwards BK. Persistent area socioeconomic disparities in US incidence of cervical cancer, mortality, stage, and survival, 1975-2000. Cancer 2004; I0I(5): I05I-57. DOI: 10.1002/cncr. 20467.

II.Graham JE, Mishra A. Global challenges of implementing human papillomavirus vaccines. Int J Equity Health 20II;10:27. DOI: 10.1186/ |475-9276-10-27.

12. Medeiros LR, Rosa DD, Da-Rosa MI, Bozzetti MC, Zanini RR. Efficacy of human papillomavirus vaccines: a systematic quantitative review. Int J Gynecol Cancer 2009;19(7): I 16676. DOI: I0.1 I I I/IGC.0b0 I3e3 I8Ia 3dI00.

13. Licht AS, Murphy JM, Hyland AJ, Fix BV, Hawk LW, Mahoney MC. Is use of the human papillomavirus vaccine among female college students related to human papillo-mavirus knowledge and risk perception? Sex Transm Infect 201 0;86(I):74-8. DOI: 10.1 I 36/sti.2009.037705.

I4. Dempsey A, Cohn L, Dalton V, Ruffin M. Worsening disparities in HPV vaccine utilization among 1926 year old women. Vaccine 20 I I;29(3):52834. DOI: $10.1016 / j$.vaccine. 2010 . I0.05I.

15. Limia A, Pachón I. Coverage of human papillomavirus vaccination during the first year of its introduction in Spain. Euro Surveill 20I I; 16(21): pii $=19873$. DOI: 10.2807/ese. |6.21.|9873-en.

16. Rondy M, Van-Lier A, Van-deKassteele J, Rust L, De-Melker H. Determinants for HPV vaccine uptake in the Netherlands: A multilevel study. Vaccine 2010;28(9):2070-5. DOI: 10.1016/j.vaccine.2009.12.042.

17. Binagwaho A, Wagner CM, Gatera M, Karema C, Nutt CT, Ngaboa F. Achieving high coverage in Rwanda's national human papillomavirus vaccination programme. Bull World Health Organ 2012;90(8):623-8: DOI: I0.247I/BLT.I I.097253.

18. Household Integrated Economic Survey (HIES) 20I I- 12. 20 I3, Pakistan Bureau of Statistics: Pakistan. Available from URL: http://www. pbs.gov.pk/content/householdintegrated-economic-survey-hies2015-16 (Accessed on: 02-0I-2018). 
19. Drug Information System. Ava ilable from URL: Www.druginfosys.com. (Accessed on: 07-0I-20I8).

20. Pandey D, Vanya V, Bhagat S, Binu VS, Shetty J. Awareness and attitude towards human papillomavirus (HPV) vaccine among medical students in a premier medical school in India. PLoS One 20I2;7(7):e406/9. DOI: I0.137|/journal.pone.00406/9.

21. Hoque ME, Van Hal G. Acceptability of Human Papillomavirus Vaccine: A Survey among Master of Business Administration Students in KwaZuluNatal, South Africa. Biomed Res Int 20I 4;20। 4:257807. DOI: $10.1155 / 2014 / 257807$.

22. DiAngi YT, Panozzo CA, RamogolaMasire D, Steenhoff AP, Brewer NT.
Across-sectional study of HPV vaccine acceptability in Gaborone, Botswana. PLoS One 20I I;6(I0):e2548I. DOI: 10.1371/journal.pone.002548I.

23. Joy T, Sathian B, Bhattarai C, Chacko J. Awareness of cervix cancer risk factors in educated youth: a crosssectional, questionnaire based survey in India, Nepal, and Sri Lanka. Asian Pac J Cancer Prev 20 I ; I2(7): I 707 12.

24. Hopkins TG, Wood N. Female human papillomavirus (HPV) vaccination: global uptake and the impact of attitudes. Vaccine 20I3;3I(I3):I673-9. DOI: I0.10I6/ j.vaccine.2013.01.028.

25. McCaffery K, Forrest S, Waller J, Desai M, Szarewski A, Wardle J.
Attitudes towards HPV testing: a qualitative study of beliefs among Indian, Pakistani, African-Caribbean and white British women in the UK. $\mathrm{Br} J$ Cancer 2003. 88(I):42-6. DOI: 10.1038/sj.bjc. 6600686

26. Jawaid A. Cervical cancer vaccine in Pakistan: let's start thinking. Int J Infect Dis 2008;12(2):217. DOI: 10.1016/j.jijid.2007.04.0I4

27. Bharadwaj M, Hussain S, Nasare V, Das BC. HPV \& HPV vaccination: issues in developing countries. Indian J Med Res 2009; I 30(3):327-33.

28. Bhatla N, Joseph E. Cervical cancer prevention \& the role of human papillomavirus vaccines in India. Indian J Med Res 2009; 130(3):33440.

\section{AUTHORS' CONTRIBUTIONS}

Following authors have made substantial contributions to the manuscript as under:

SG: Concept, interpretation of data, critical review, final approval of the version to be published.

FA: Acquisition of data, drafting the manuscript, critical review, final approval of the version to be published.

TH: Study design, drafting the manuscript, final approval of the version to be published.

LB: Acquisition of data, critical review, final approval of the version to be published.

SN: Acquisition, analysis \& interpretation of data, drafting of manuscript, final approval of the version to be published.

MAM: Acquisition, analysis \& interpretation of data, final approval of the version to be published.

Authors agree to be accountable for all aspects of the work in ensuring that questions related to the accuracy or integrity of any part of the work are appropriately investigated and resolved.

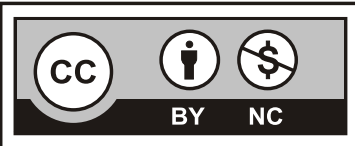

This is an Open Access article distributed under the terms of the Creative Commons Attribution-NonCommercial 2.0 Generic License.
KMUJ web address: www.kmuj.kmu.edu.pk

Email address: kmuj@kmu.edu.pk 